\section{Pancreas under scrutiny}

As development proceeds, cells acquire new fates - a process that has classically been recognized by changes at the phenotypic level. But what about the events that precede differentiation? What about the commitment stage? In a recent issue of Developmental Cell, Chiang and Melton report a new method that might allow us to answer these questions. Based on single-cell PCR and DNA microarray analysis, it creates gene expression in single cells from a developing pancreas, and its results have led the authors to propose a model for pancreatic cell development.

To determine the transcription profiles of single pancreatic cells, the authors modified a previously existing method for PCR-based cDNA amplification. cDNAs were then hybridized to custom microarrays of 95 pancreatic genes that included transcription factors, signalling molecules and controls.

The authors used their method to profile single cells that had been isolated from an E10.5 mouse pancreatic epithelium. Although at this stage the epithelium is morphologically homogeneous, on the basis of their profiling the authors distinguished six cellular subtypes. For example, there were cells (type I) that expressed only $P d x 1$, $N k x 2.2$ and $N k x 6.1$, those that also expressed P48 (type II) and those that also expressed Ngn3 (type III).

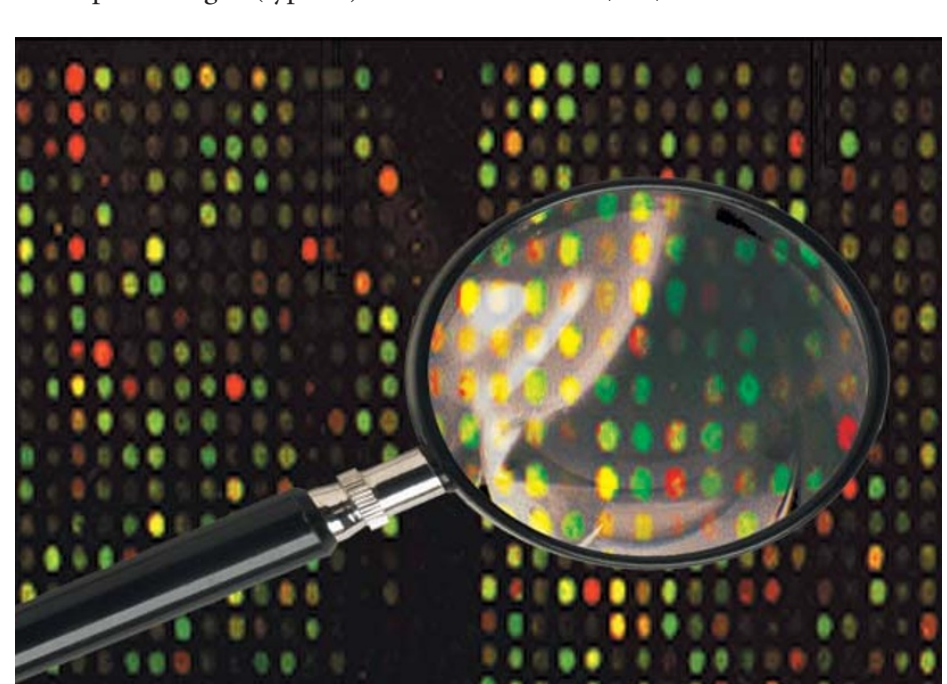

Because $P d x 1$ is the earliest pancreatic marker, without which the pancreas fails to develop, Chiang and Melton suggest that type I cells are good candidates for early pancreatic stem cells. Because type II cells express $P 48$, which is a marker for the exocrine pancreas, and $N k \times 2.2$ and $N k x 6.1$, which are required for endocrine cell differentiation, type II cells might represent progenitors of many distinct lineages. Looking at the different combinations of expressed a model for pancreatic cell differentiation - each step in the model corresponds to a cell type that is associated with a different expression signature.

The new method of Chiang and Melton can, of course, be applied to any developing organ, similar studies can be performed at different developmental time-points, and it might also be used for tumour-cell profiling. Importantly for those who study the pancreas and are interested in diabetes treatment, it might have finally provided a way to identify pancreatic stem cells.

Magdalena Skipper

\section{(1) References and links} ORIGINAL RESEARCH PAPER Chiang, M. -K. \& Melton, D. A. Single-cell transcript analysis of pancreas development. Dev. Cel/ 4, 383-393 (2003)

FURTHER READING Edlund, H. Pancreatic organogenesis - developmental mechanisms 3, 524-532 (2002) genes allowed the authors to propose .

\section{ETHICS WATCH}

\section{DNA, nurture and parenthood}

Nature or nurture? This familiar question has been given a poignant twist with the marriage of an old issue and a recent genetic technology. DNA fingerprinting is increasingly being used in family disputes ${ }^{1}$. Women use it to seek support from

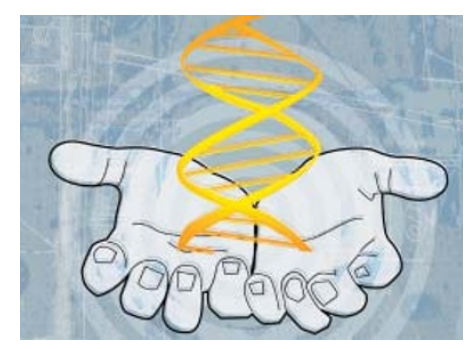
the biological father of their child, and men in divorce disputes are being advised by their lawyers to have their children tested. Any child found not to be their biological offspring becomes a card to be played in the divorce settlement. In some cases, men who have raised a child for many years are being urged to cut off all contact. Anglo-American law has long embodied the presumption that any child born to a married couple was the husband's. This legal rule was probably less motivated by any tender regard for the health of the marriage or the well-being of the child than by the determination of the state to make certain that someone - other than the state - be financially responsible for the child ${ }^{2}$. Exceptions were rare. Impotence or sterility could overcome the presumption. An absent husband could invoke the 'four seas' rule. But in general, despite evidence indicating that a non-trivial number of children are not the biological offspring of the husband of their mother, law has assigned paternal rights and obligations to him. The paternity blood test, developed by Landsteiner in 1901, could exclude some men as possible fathers, but it could not show that any particular man was, indeed, the father ${ }^{3}$.

DNA relationship testing changed that. It is now possible to establish beyond reasonable doubt whether a first-degree biological relationship exists. The ethical question is, so what? When a man has raised a child as his own for one, five or fifteen years, are they not parent and child? The Romans had a practice of raising children who were not their offspring. They were called 'alumna' or 'alumnus' and the relationship, being voluntary, was regarded as superior to mere ties of biology $y^{4}$. Whether the Romans got the details correct is not important; they understood that a relationship between adults and children nurtured over years of continuing care and growing mutual affection mattered, with or without a biological connection. Today, adoptive parents and the children that they raise and love understand this well. When a technology — such as DNA relationship testing undermines the settled social policy that ties legal parenthood to rearing parenthood, the law must adapt. Our best ethical understanding of what it means to be a parent should guide the law — not the anger of 'duped dads' or a simple-minded conception in which a genetic test trumps a decade of diapers, bedtime stories and trust. After all, it is in our nature to nurture, and law should affirm, not undermine, that truth.

Thomas H. Murray, The Hastings Center e-mail:murrayt@thehastingscenter.org REFERENCES 'Stanley, A. So, who's your daddy? In DNA tests, TV finds elixir to raise ratings. New York Times C1 (19 March 2002) $\left.\right|^{2}$ Grossberg, M. Governing the Hearth: Law and Family in Nineteenth Century America (Univ. of North Carolina Press, North Carolina, 1985) | ${ }^{3}$ Glennon, T. Somebody's child: evaluating the erosion of the marital presumption of

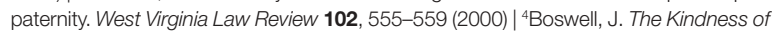
Strangers: The Abandonment of Children in Western Europe from Late Antiquity to the Strangers: The Abandonment of Children in
Renaissance (Pantheon, New York, 1988) 